\title{
THE LIFE-HISTORY OF APAUSTUS LASCIVIA, ROSENSTOCK.
}

\author{
By G. A. Waterhouse.
}

Apaustus lascivia, Rosenstock, Ann. Mag. Nat. Hist. (5), xvi. (1885), p. 378 , Pl. xI. fig. 1 .

In January of the present year it was my good fortune to find at Rose Bay the larvæ of a small skipper, of whose life-history I can find no record. The larva were found feeding on a grass, Imperata arundinacea. Each larva conceals itself by uniting the edges of the leaves so as to form a sheath, inside which it remains. When feeding, which is usually at night, it protrudes its head just outside this sheath and nibbles the edges of it. When one of these sheaths is eaten up, the larva makes another retreat. The larva, when full grown, is one inch in length, being pale green in colour; the two segments nearest the head are smallest. When half-grown the head is totally black, but when full grown is very light brown with the black $\mathrm{V}$-shaped marking common to the larvæ of this family and a black ring round the outer edge of the head. The larva when full grown constructs a sheath similar to the one it feeds in, closes up both ends and casts its skin. The pupa is at first a pale olive-green, gradually turning a light brown. The wings change colour first. The pupa is about half an inch long. It usually remains in the pupal state from ten to twelve days. This butterfly is very common in February, when hundreds may be seen. It is found in gullies wherever its food-plant occurs, being very plentiful in Double Bay Gully.

Mr. Olliff has described and figured* the details of the lifehistory of another species of this genus, A. agraulia, Hewitson, its food-plant being couch grass.

When I bred this insect I also bred another skipper, but I hesitate to give its life-history, as I have not yet determined it specifically, the nomenclature of the Hesperide being very confused at present.

* Ann. Mag. Nat. Hist. (5), 1888, p. 360, Pl. xx. figs. $3 a, 3 b$. 


\section{$2 \mathrm{BHL}$ Biodiversity Heritage Library}

Waterhouse, Gustavus A. 1897. "The life-history of Apaustus lascivia, Rosenstock." Proceedings of the Linnean Society of New South Wales 22, 244. https://doi.org/10.5962/bhl.part.12718.

View This Item Online: https://www.biodiversitylibrary.org/item/22896

DOI: https://doi.org/10.5962/bhl.part.12718

Permalink: https://www.biodiversitylibrary.org/partpdf/12718

\section{Holding Institution}

MBLWHOI Library

\section{Sponsored by}

MBLWHOI Library

\section{Copyright \& Reuse}

Copyright Status: NOT_IN_COPYRIGHT

This document was created from content at the Biodiversity Heritage Library, the world's largest open access digital library for biodiversity literature and archives. Visit BHL at https://www.biodiversitylibrary.org. 